\title{
PENGARUH LATIHAN LADDER DRILL TERHADAP PENINGKATAN KELINCAHAN PEMAIN SEPAKBOLA
}

\author{
Gumilar Mulya ${ }^{1}$, Haikal Millah ${ }^{2}$ \\ ${ }^{1-2}$ Pendidikan Jasmani, Universitas Siliwangi, Tasikmalaya \\ gumilarmulya@unsil.ac.id, haikal@unsil.ac.id
}

\begin{abstract}
Abstrak. Penelitian ini bertujuan untuk melaporkan hasil percobaan satu bentuk latihan leader drill dalam meningkatkan kelincahan atlet sepakbola pada salah satu klub perguruan tinggi di Indonesia. Data penelitian diambil setelah dilakukan percobaan selama 16 kali pertemuan 3 kali dalam satu minggu pada 21 atlet dengan menggunakan instrumen tes agility Zig-Zag Run. Hasil penelitian menunjukan adanya peningkatan kelincahan dan kecepatan lari atlet sepakbola setelah diberikan latihan leader dril secara teratur mengikuti prinsip-prinsip latihan.
\end{abstract}

Kata Kunci: Latihan, Leader drill, Kelincahan

\section{PENDAHULUAN}

Sepakbola membutuhkan postur unipedal untuk melakukan sebagian besar gerakan teknis seperti menembak, menggiring bola, atau mengoper, sehingga kemampuan keseimbangan dinamis adalah prasyarat keterampilan teknis. Intensitas tinggi dan tindakan eksplosif dengan tuntutan teknis yang tinggi, seperti berlari, mengubah arah, melompat, menendang, dan menendang, memiliki dampak besar dalam menentukan hasil pertandingan. (Warren \& Nathan, 2013).

Penampilan permainan sepakbola bersifat multifaktorial dan membutuhkan berbagai kualitas fisik, termasuk kecepatan, daya tahan, kelincahan, koordinasi, kekuatan, keseimbangan, serta keterampilan persepsi dan kognitif. (Matteo, Massimo and Chiarella, 2016).

Salah satu komponen fisik dalam permainan sepakbola adalah kelincahan, kelincahan merupakan gerakan seluruh tubuh yang cepat dengan perubahan kecepatan atau arah dalam menanggapi rangsang. (J. M. Sheppard a \& W. B. Young, 2007).
Pengembangan kecepatan, kemampuan melompat dan kelincahann melalui latihan yang khusus harus ditekankan dalam program pelatihan sepak bola (Nikolaos Manouras, et al., 2016).

Tidak hanya di masyarakat, sepakbola juga berkembang di tingkat universitas, terbukti dengan adanya UKM sepakbolapada setiap universitas di Indonesia. Salah satunya pada UKM sepakbola Universitas Siliwangi. Dengan adanya Liga Mahasiswa Piala Menpora pada tahun 2018 ini, membuat UKM setiap kampus lebih aktif lagi untuk berlatih guna dapat mewakili provinsinya sebagai wakil pada putaran akhir Nasional. Prestasi UKM sepakbola Universitas Siliwangi meraih juara 1 pada Zona Daerah (putaran 1).

Dalam bermain sepakbola perlunya kondisi yang sangat prima baik dari teknik, fisik dan mental. Kenyataan di lapangan tidak sesuai dengan harapan, masih banyak atlet-atlet belum dapat tampil maksimal pada saat bertanding. Dari beberapa faktor kendala itu yang 
paling mencolok adalah faktor kelincahan (agility) atlet.

Dari penjelasan di atas bahwa kondisi fisik menjadi masalah padaUKM sepakbola Universitas Siliwangi tetapi dari beberapa kondisi fisik tersebut faktor kelincahan yang menjadi masalah utama. Kelincahan seorang pemain terlihat pada saat pemain mau melakukan menggiirng bola masih belum optimal. Menurut Bompa, (2009: 324) mengatakan agility adalah kemampuan untuk berhenti, cepat merubah arah, mempercepat dalam menanggapi suatu isyarat eksternal. Dari penjelasan itu kelincahan merupakan kemampuan seseorang untuk mengambil keputusan bergerak dengan cepat, berhenti, berubah arah dengan efektif dan efisien keberbagai posisi dan arah yang dikehendaki tanpa kehilangan keseimbangan pada saat bermain sepakbola.

Latihan mempunyai makna sebagai proses perubahan tingkah laku sebagai akibat adanya interaksi antara individu dengan lingkungannya Sukadiyanto dan Dangsina Moeloek (2011: 1) mengatakan bahwa " Pada prinsipnya latihan merupakan suatu proses perubahan arah yang lebih baik, yaitu meningkatkan: kualitas fisik, kemampuan fungsional peralatan tubuh, dan kualitas psikis anak latih". Lubis, Johansyah (2013: 20) mengatakan bahwa "model latihan adalah proses jangka panjang secara kontinyu dan berubah secara terus menerus karena model latihan akan berkembang berkaitan dengan atletnya".

Menurut Bompa (2009: 4) bahwa tujuan latihan:
a. Untuk
mencapai dan meningkatkan perkembangan fisik secara multilateral.
b. Untuk meningkatkan dan mengembangkan fisik spesifik,

sesuai dengan kebutuhan olahraga yang ditekuni

c. Untuk menghaluskan dan menyempurnakan teknik dan cabang olahraganya.

d. Untuk meningkatkan dan mempertahankan teknik, taktik dan strategi yang diperlukan.

e. Untuk mengelola kualitas kemampuan.

f. Untuk menjamin dan menggunakan persiapan individu maupun tim secara optimal.

g. Untuk memperkuat tingkat kesehatan tiap atlet.

h. Untuk mencegah terjadinya cidera.

i. Untuk meningkatkan pengetahuan teori.

Proses latihan dalam olahraga harus direncanakan dengan baik terutama dalam perencanaan program latihan harus mengacu pada multilateral dan spesialisasi. Seperti yang dikatakan Bompa (2009: 31) bahwa "Pengembangan kemampuan atlet secara kesluruhan mengandung pelatihan secara seimbang antara multilateral dan spesialisasi”. Secara umum, pada awal pengembangan pelatihan atlet harus menitik beratkan pada pengembangan multilateral, dengan sasaran pengembangan kondisi fisik secara menyeluruh.

Tahapan spesialisasi untuk olahraga merupakan langkah kedua setelah anak melakukan latihan multilateral pada tahapan usia sebelumnya yaitu dikisaran umur 10-12. Setelah mencapai umur antara 13-14 tahun, maka dilanjutkan dengan program spesialisasi, yang merupakan proses latihan spesifik suatu kecabangan olahraga dengan materi peningkatan teknik-teknik dasar yang telah dimilikinya agar dapat menguasai komponen gerak yang tepat (Bompa, 2009: 37).Perencanaan suatu latihan harus disusun oleh seorang pelatih yang 
ahli dan pengalaman, dan pencapaian tujuan dilakukan secara bertahap dan berkesinambungan antara tujuan pertama dan kedua saling terkait dan bersambung untuk tujuan selanjutnya (Bompa, 2009: 235).

Menurut Bompa (2009: 241) bentuk suatu latihan dapat dilakukan jika meliputi 4 klasifikasi latihan, yaitu:

1) Learning, merupakan tahapan latihan mempelajari ketepatan keterampilan baru atau taktik permainan. Dalam hal ini pelatih harus menggunakan tahapan awal ini sebagai bagian dari struktur organisasi latihan.

2) Repetition, merupakan langkah kedua yang berlatih ketrampilan yang spesifik secara berulangulang

3) Skill Perfection, merupakan kelanjutan dari tahapan sebelumnya yang bertujuan meningkatkan kemampuan teknik yang dimiliki dan dipergunakan dalam permainan yang sebenarnya.

4) Assessment, merupakan tahapan penilaian yang dilakukan pelatih terhadap penampilan dan responsive dari atlit secara psikologi dalam suatu latihan.

Kelincahan. Giles (2007: 9) menjelaskan pengertian kelincahan secara umum yaitu "efisiensi gerakan di seluruh rantai kinetik terlepas dari keterampilan yang dieksekusi". Bompa (2009: 324) mengatakan agility adalah kemampuan untuk berhenti, cepat berubah arah, mempercepat dalam menanggapi suatu isyarat eksternal.

Pendapat Brian (2005: 55) tentang sebuah agility sebagai "The multi movement demands of field and court games dictate a revaluation of the traditional approach to the development of agility. this demans a systematic multi factored approach that result in significant improvement in game speed".
Bahwa agility tuntutan gerakan di berbagai bidang dan pendekatan multiterfaktor sistematis yang menghasilkan perbaikan yang signifikan dalam kecepatan permainan. Agility menurut Widiastuti (2011: 125) adalah kemampuan untuk mengubah arah atau posisi tubuh dengan cepat dan dillakukan dengan bersama-sama dengan gerakan lainnya.

Hasil penelitian Zisis, et al., (2016) gerakannya hanya melompat ke depan dan ke atas, sedangkan Warren dan Nathan (2013) melatih kelincahan permainan samll-side dan latihan merubah arah. Agar atlet sepakbola memiliki kemampuan mengubah arah dan akurat. Reynolds (2011) menemukakan Ladder drills merupakan cara yang terbaik dan menyenangkan untuk mengajarkan keterampilan gerak. Meskipun gerakan linear dan lateral adalah biomekanik sederhana, dengan kombinasi gerak ini dapat menjadi komplek.

Latihan ladder drills termasuk latihanyang dapat meningkatkan kelincahan. Hal ini sesuai dengan pendapat Reynolds (2011: 17) mengatakan bahwa "ladder drills atau tangga latihan adalah cara yang terbaik dan menyenangkan untuk mengajarkan kete-rampilan gerak. Meskipun gerakan linear dan lateral adalah biomekanik sederhana, dengan kombinasi gerak ini dapat menjadi komplek".

Peningkatan

kemampuan kelincahan pemain dapat diperoleh karena latihan yang dilakukan sesuai dengan menggunakan teori prinsip latihan. Jadi dengan pemberian beban yang sistematis, berulang-ulang dan jumlah beban yang semakin bertambah akan meningkatkan kemampuan terhadap kegiatan yang dilakukan oleh seorang pemain. Tujuan serta sasaran utama dari latihan adalah untuk membantu atlet atau pemain 
meningkatkan keterampilannya semaksimal mungkin (Harsono, 2017: 100). Dengan melakukan latihan yang sistematis, terstruktur, berulang- ulang, dan jumlah beban latihan kian hari kian meningkat, akan mampu menghasilkan tujuan dari latihan yang dilakukan. Selain itu, Budiwanto (2012: 35) menjelaskan "cara mengembangkan kelincahan ialah dengan latihan berulang-ulang gerakan dengan frekuensi yang banyak, meningkatkan kelincahan gerakan.

Intensitas adalah ukuran yang menunjukkan kualitas (mutu) suatu rangsangan atau pembebanan. Untuk menentukan besarnya ukuran intensitas antara lain menurut Sukadiyanto dan Moeloek (2011 : 26) dengan cara :

\section{a. 1 RM (repetition maximum)}

Sukadiyanto(2001 : 26), 1 RM sebagai salah satu ukuran intensitas yang bentuknya adalah mengukur kemampuan otot atau sekelompok otot untuk mengangkat atau melawan beban secara maksimal dalam satu kali kerja. 1 RM sering kali digunakan dalam hal menentukan beban latihan dengan ukuran berat dan jumlah repetisi maksimal yang dapat dilakukan dalam waktu tertentu. Misalnya, kemampuan maksimal seseorang mengangkat beban seberat 200 kiligram, kalau ditambah sedikit saja tidak akan mampu mengangkat, sebaliknya kalau dikurangi akan terasa lebih ringan. Repetisi maksimaldapat juga digunakan untuk mengukur kemampuan intensitas seseorang dengan cara melakukan kerja yang sama dan berkali-kali. Contohnya antara lain, kemampuan seseorang dalam melakukan sit up, push up, atau back up sebanyak-banyaknya sampai dengan tidak dapat melakukannya lagi secara sempurna.

b. Jumlah repitisi (ulangan) per waktu tertentu (menit/detik)

Sukadiyanto dan Moeloek (2011 : 26) menyebutkan jumlah repetisi dapat sebagai ukuran intensitas, yaitu dengan cara satu bentuk aktivitas dalam waktu tertentu dan mampu melakukannya dalam beberapa ulangan. Contohnya, seorang yang melakukan aktivitas seperti sit up, back up, atau push up sebanyak-banyaknya dalam waktu 30 detik mampu melakukan 25 kali.

\section{METODE}

Tujuan yang ingin dicapai dalam penelitian ini adalah untuk mengetahui pengaruh latihan ladder drill terhadap peningkatan kelincahan pemain UKM sepakbola Universitas Siliwangi Tasikmalaya. Penelitian ini dilakukan di Lapang Depan Universitas Siliwangi.

Metode yang digunakan dalam penelitian ini adalah metode PreExsperimental Designs yaitu hasil eksperimen yang merupakan variabel dependen, hal ini dapat terjadi, karena tidak adanya variabel kontrol dan sampel tidak dipilih secara random. (Sugiyono, 2010: 109).

Dalam penelitian ini perubahan yang diamati adalah bentuk latihan ladder drill sebagai variabel perlakuan. Kelincahan UKM sepakbola Universitas Siliwangi sebagai variabel terikat, serta mengamati perbandingan hasil tes awal dan tes akhir agility.

Desain penelitian ini dengan menggunakan One-Group PretestPosttest Design yaitu terdapat tes awal sebelum diberikan perlakuan, perlakuan dapat diketahui lebih akurat dengan membandingkan keadaan sebelum dan sesudah diberi perlakuan Sugiyono (2010: 110). dengan gambar sebagai berikut: 


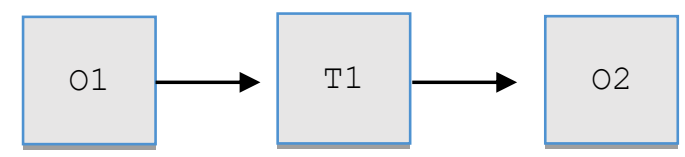

Gambar 1. Desain penelitian The One Group Pretest-Posttest design

Sumber: Sugiyono, 2010: 111.

Keterangan gambar :

O1 :Tes Awal Agility

T1 :Perlakuan terhadap sampel, dalam bentuk rangkaian latihan Ladder drill

O2 :Tes Akhir Agility

Populasi pada penelitian ini adalah seluruh pemain sepakbola UKM Universitas Siliwangi berjumlah 21 orang. Sampel penelitian ini berjumlah 21 orang yakni seluruh anggota populasi. Dengan demikian maka teknik pengambilan sampel adalah menggunakan teknik total sampling atau sampel jenuh.

Sampel jenuh menurut Sugiyono (2010:125) dikatakan bahwa sampel jenuh adalah teknik pengambilan sampel seluruh anggota populasi. Pengumpulan data dalam penelitian ini menggunakan tes awal dan tes akhir dengan menggunakan tes agility Zig-Zag Run (Widiastuti, 2015: 139).

Pengumpulan data dalam penelitian ini menggunakan tes awal dan tes akhir dengan menggunakan tes agility zig-zag run (Widiastuti, 2015: 139).

\section{Tes agility Zig-Zag Run}

Alat dan Fasilitas
a. Stopwatch
b. Alat tulis
c. Kapur

Petugas tes
a. Pemanggil tes
: 1 orang
b. Pengamat waktu
: 1 orang
c. Pencatat hasil
: 1 orang
d. Pengamat tes
: 2 orang

\section{Pelaksanaan tes}

a. Teste berdiri di garis A, bila ada aba-aba "ya", ia lari Ke B, $\mathrm{C}$ dan $\mathrm{D}$ mengikuti arah panah sesuai diagram sampai batas finish;

b. Tes dilaksanakan 1 Kali Putaran;

c. Catat waktu tempuh terbaik dari 3 kali percobaan dan dicatat sampai sepersepuluh detik.

Berikut gambar tes agility zig-zag run;

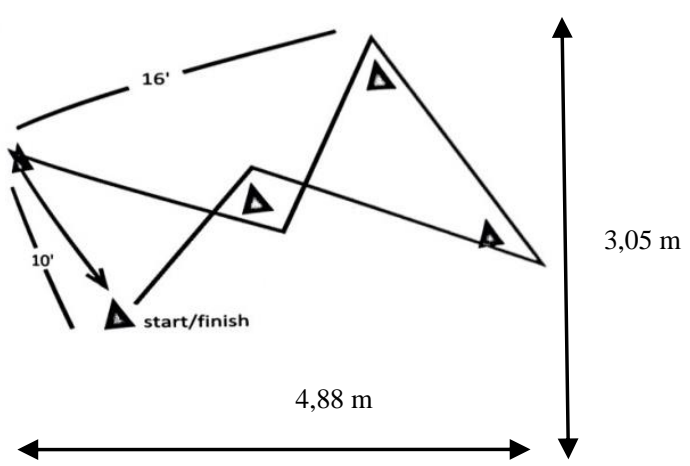
B

Gambar 2. Tes Agility Zig-zag Run Sumber: Widiastuti (2015: 139)

Setelah melakukan tes awal kemudian diberikan perlakuan berupa latihan Ladder Drill. Perlakuan ini dilaksanakan langsung dimulai dengan pemanasan dilanjutkan latihan inti.

\section{Latihan Ladder drill}

Pelaksanaan latihan ada2 latihan ladder drill yang digunakan:

a. Ladder drill Cross Country Ski

b. Ladder drill Icki Shuffle

Tujuan : Melatih Agility

Cara melakukannya :

1. Pertama - tama pemain berada di depan ladder drill

2. Setelah itu melakukan gerakan cross country ski dengan cepat

3. Selanjutnya melakukan gerakan icki shuffle 
4. Berulai dari arah ke kiri dan berputar sampai 8 arah yang telah ditentukan.

5. Gerakan dilakukan dengan cepat / maksimal.

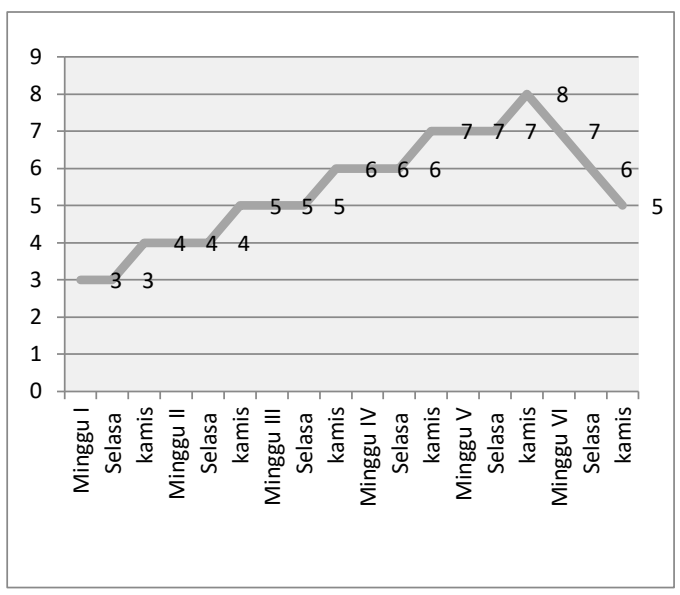

Gambar 3. Grafik latihan ladder drill

Catatan

a. Dosis ditentukan $80 \%$ dari test maksimal per individu.

b. Gerakan dilakukan secara maksimal.

c. Latihan dilakukan per individu.

Dalam penelitian ini untuk melihat ada tidaknya perubahan berdasarkan pada hasil tes awal, maka dapat menggunakan terotitis yang dikemukakan oleh Bompa (2015: 127) tentang durasi latihan yaitu: "The volume of anatomical adaptation session sould fall between 16 and 32 total sets, a hypertrophy session between 16 and 24 (and less than one hour in duration), a maximum strength session between 16 and 24, a power seassion between 10 and 16, and a power endurance or muscle endurance short session between 4 and 12". Dapat disimpulkan bahwa dalam melakukan sebuah latihan untuk dapat merubah kondisi fisik dalam hal ini kelincahan bahwa diperlukan banyaknya jumlah latihan antara 16 dan 24 pertemuan, dalam penelitian ini peneliti mengambil 18 pertemuan dalam perlakuan latihan untuk meningkatkan kelincahan dengan menggunakan latihan Ledder Driil.

Rancangan analisis data yang dipergunakan dalam penelitian ini adalah:

1. Uji normalitas dengan uji Komogrov - Smimov (SPSS 21)

2. Uji Homogenitas dengan uji One - Way ANOVA (SPSS 21)

3. Uji Hipotesis (analisis perbandingan rata-rata) Paired samples $T$ test (SPSS 21). (Trihendradi, 2013)

\section{HASIL DAN PEMBAHASAN}

Sesuai dengan permasalahan dalam penelitian ini, berikut ini adalah hasil tes zig-zag runsebelum dan sesudah mengikuti latihan Ladder Drill. Untuk lebih jelasnya, berikut ini adalah data hasil tes tersebut pada Tabel 1. di bawah ini.

Tabel 1. Data Hasil Tes Awal dan Tes Akhir Kelincahan

\begin{tabular}{|c|c|c|c|}
\hline No & Nama & $\begin{array}{c}\text { Tes } \\
\text { Performance } \\
\text { Awal }\end{array}$ & $\begin{array}{c}\text { Tes } \\
\text { Performance } \\
\text { Akhir } \\
\end{array}$ \\
\hline 1 & AHMAR ZIMARNA & 5,4 & 4,9 \\
\hline 2 & ANGGARA YUDHA & 7,2 & 6,13 \\
\hline 3 & KRIS MAULANA & 7,6 & 6,8 \\
\hline 4 & WAHYU DANUR & 7,2 & 6,38 \\
\hline 5 & ROBI SAPUTRA & 7,1 & 7,1 \\
\hline 6 & RIDWAN HIDAYAT & 7,2 & 6,76 \\
\hline 7 & ADITYA PRATAMA & 7,5 & 5,6 \\
\hline 8 & ALFIN ALFARIZI & 7,8 & 5,94 \\
\hline 9 & $\begin{array}{l}\text { ABDURAHMAN } \\
\text { WAHID }\end{array}$ & 7,9 & 5,34 \\
\hline 10 & RANGGA HENDRIA & 6,5 & 6,1 \\
\hline 11 & $\begin{array}{l}\text { ALOARMAN } \\
\text { SETIAWAN }\end{array}$ & 7,5 & 7,5 \\
\hline 12 & GIAN NOOR R & 8 & 5,5 \\
\hline 13 & JAMMIE GENARDI & 8,4 & 5,96 \\
\hline 14 & FERI IRAWAN & 6,3 & 5,92 \\
\hline 15 & MUKHLIS SULAM M & 7,3 & 6,62 \\
\hline 16 & KALAM SIDIK & 5,9 & 5,7 \\
\hline 17 & TEGUH Y & 8,2 & 5,13 \\
\hline
\end{tabular}




\begin{tabular}{llcc}
18 & DANI R & 7,7 & 6,6 \\
\hline 19 & ZULFIKAR & 5,7 & 5,3 \\
\hline 20 & LUKMAN EFENDI & 6,8 & 5,57 \\
\hline 21 & ROBY GUMELAR & 7,7 & 5,48 \\
\multicolumn{4}{c}{$\begin{array}{c}\text { Sumber: Data penelitian } \\
\end{array}$}
\end{tabular}

Dari data tersebut dapat dijelaskan mengenai deskripsi statistik melalui software SPSS dengan rincian data pada tabel 2. di bawah ini:

\section{Tabel 2. Deskripsi Data Penelitian}

Paired Samples Statistics

\begin{tabular}{rccccc}
\hline & Mean & $\mathrm{N}$ & $\begin{array}{c}\text { Std. } \\
\text { Deviation }\end{array}$ & $\begin{array}{c}\text { Std. } \\
\text { Error } \\
\text { Mean }\end{array}$ \\
\hline \multirow{2}{*}{ Pair 1 } & $\begin{array}{c}\text { Tes } \\
\text { Awal }\end{array}$ & 7.1857 & 21 & .81932 & .17879 \\
\cline { 2 - 6 } & $\begin{array}{c}\text { Tes } \\
\text { Akhir }\end{array}$ & 6.0157 & 21 & .68730 & .14998
\end{tabular}

Langkah selanjutnya dalam penelitian ini adalah melakukan pengujian persyaratan analisis untuk menentukan langkah-langkah yang ditempuh dalam pengolahan dan analisis data.

\section{Uji Normalitas}

Uji normalitas dengan uji Kolmogorov - Smimov (SPSS 21), yaitu untuk menentukan data normal atau tidak. Pengajuan asumsi dipilih berasal dari sebuah distribusi populasi yang normal atau tidak normal. Kadir (2010: 107)

Tabel 3. Uji Normalitas Data Tes

Awal

One-Sample Kolmogorov-Smirnov

\begin{tabular}{llr}
\multicolumn{1}{c}{$\begin{array}{c}\text { One-Sample Kolmogorov-Smirnov } \\
\text { Test }\end{array}$} & Tes Awal \\
\hline N & & 21 \\
\hline \multirow{2}{*}{ Normal Parameters $^{\text {a,b }}$} & Mean & 7.1857 \\
\cline { 2 - 3 } & $\begin{array}{l}\text { Std. } \\
\text { Deviation }\end{array}$ & .81932 \\
\hline \multirow{2}{*}{$\begin{array}{l}\text { Most Extreme } \\
\text { Differences }\end{array}$} & Absolute &, 174 \\
\cline { 2 - 3 } & Positive &, 085 \\
\cline { 2 - 3 } & Negative &,- 174
\end{tabular}

\begin{tabular}{lr} 
Test Statistic &, 174 \\
\hline Asymp. Sig. (2-tailed) &, $098^{c}$ \\
\hline
\end{tabular}

a. Test distribution is Normal.

b. Calculated from data.

c. Lilliefors Significance Correction.

Tabel 4. Uji Normalitas Data Tes

Akhir

\begin{tabular}{|c|c|c|}
\hline \multicolumn{2}{|c|}{$\begin{array}{c}\text { One-Sample Kolmogorov- } \\
\text { Smirnov Test }\end{array}$} & \multirow{2}{*}{$\begin{array}{r}\text { Tes Akhir } \\
21\end{array}$} \\
\hline $\mathrm{N}$ & & \\
\hline \multirow{2}{*}{$\begin{array}{l}\text { Normal } \\
\text { Parameters }\end{array}$} & Mean & 6.0157 \\
\hline & $\begin{array}{l}\text { Std. } \\
\text { Deviation }\end{array}$ & .68730 \\
\hline \multirow{3}{*}{$\begin{array}{l}\text { Most Extreme } \\
\text { Differences }\end{array}$} & Absolute & 108 \\
\hline & Positive & , 108 \\
\hline & Negative &,- 088 \\
\hline \multicolumn{2}{|l|}{ Test Statistic } & 108 \\
\hline \multicolumn{2}{|c|}{ Asymp. Sig. (2-tailed) } &, $200^{\mathrm{c}, \mathrm{c}}$ \\
\hline
\end{tabular}

a. Test distribution is Normal.

b. Calculated from data.

c. Lilliefors Significance Correction.

d. This is a lower bound of the true significance.

Berdasarkan data tersebut maka data penelitian berdistribusi normal karena hasil uji normalitas dari tes awal $(0,098)$ dan tes akhir $(0,200)$ lebih besar dari 0,05 . 
2. Uji Homogenitas

Pengujian homogenitas ini untuk menjaga komparabilitas terutama untuk pengujian hipotesis tentang perbedaan rata - rata melalui statistik Uji-T dan Uji-F. Kadir (2010: 107).

\section{Tabel 5. Uji Homogenitas Data}

Test of Homogeneity of Variances

\begin{tabular}{cr|r|r|r}
\hline & $\begin{array}{l}\text { Levene } \\
\text { Statistic }\end{array}$ & df1 & df2 & Sig. \\
\hline $\begin{array}{l}\text { Based on } \\
\text { Mean }\end{array}$ &, 267 & 1 & 40 &, 608 \\
\hline $\begin{array}{l}\text { Based on } \\
\text { Tesil }\end{array}$ &, 237 & 1 & 40 &, 629 \\
\hline $\begin{array}{l}\text { Median } \\
\text { Based on } \\
\text { Median } \\
\text { and with } \\
\text { adjusted } \\
\text { df }\end{array}$ &, 237 & 1 & 37,310 &, 629 \\
\hline
\end{tabular}

\begin{tabular}{ll|l|l|l|l}
\hline $\begin{array}{l}\text { Based on } \\
\text { trimmed } \\
\text { mean }\end{array}$ &, 240 & 1 & 40 &, 627 \\
\hline
\end{tabular}

Karena nilai signifikansi dari uji homogenitas data yaitu 0,608 lebih besar dari 0,05 maka data penelitian bersifat homogen.

3. Uji Hipotesis

Uji Hipotesis (analisis perbandingan rata-rata) Paired-Samples Ttest (SPSS 21), untuk menguji perbedaan dua rerata sampel tak bebas. Esensi dari analisis perbedaan dua ratarata sampel tak bebas adalah bahwa kedua data yang ingin diuji perbedaanya berasal dari satu kelompok sampel (satu unit analisis) yang sama menghasilkan dua distribusi data. Kadir (2010: 198).

Perlu dirumuskan terlebih dahulu hipotesis nol (Ho) penelitian ini, yaitu : "Terdapat pengaruh latihan Ladder Drill terhadap peningkatan kelincahan pemain sepakbola UKM Universitas Siliwangi.”.

Adapun hasil pengujian hipotesis dapat dilihat pada Tabel 6. di bawah ini :

\section{Tabel 6. Hasil Uji T}

Paired Samples Test

\begin{tabular}{|c|c|c|c|c|c|c|c|c|c|}
\hline & & & Paired & Differen & & & & & \\
\hline & & Mean & Std. & $\begin{array}{l}\text { Std. } \\
\text { Error }\end{array}$ & $\begin{array}{r}95 \% \mathrm{C} \\
\text { Interv } \\
\text { Diff }\end{array}$ & $\begin{array}{l}\text { onfidence } \\
\text { al of the } \\
\text { erence }\end{array}$ & $\mathrm{t}$ & $\mathrm{df}$ & $\begin{array}{c}\text { Sig. (2- } \\
\text { tailed) }\end{array}$ \\
\hline & & & & & Lower & Upper & & & \\
\hline Pair1 & $\begin{array}{c}\text { Tes Awal - Tes } \\
\text { Akhir }\end{array}$ & 1.17000 & 94931 & .20716 & .73788 & 1.60212 & 5,648 & 20 & ,000 \\
\hline
\end{tabular}


Dikarenakan nilai signifikansi uji t 0,000 $<0,05$ maka kesimpulan yang dapat diambil dari uji hipotesis adalah Terdapat pengaruh latihan Ladder Drill terhadap peningkatan kelincahan pemain sepakbola UKM Universitas Siliwangi.

\section{PEMBAHASAN}

Berdasarkan pengolahan data hasil penelitian menunjukkan bahwa terdapat peningkatan kelincahan dengan menggunakan latihan ladder drill. Hal ini dikarenakan program latihan yang diterapkan dijalankan dengan baik dan benar.

Bentuk latihan ladder drillyang diberikan adalah 1) Ladder Drill Cross Country Ski, 2) Ladder Drill Icky Shuffle. Bentuk latihan ini sudah terbukti dapat meningkatkan kelincahan pada pemain sepak bola, maka bagi para pelatih bisa menerapkan bentuk latihan ini dalam program latihannya.

Penelitian ini juga ditunjang oleh kondisi sampel yang memang sedang dipersiapkan untuk menghadapi kompetisi sepakbola liga mahasiswa piala Menpora 2019. Sehingga program latihan peningkatan yang diberikan peneliti bisa dilakukan secara seksama sesuai dengan kebutuhan pelatih UKM sepakbola dalam peningkatan kelincahan.

\section{KESIMPULAN}

Berdasarkan pada hasil pengolahan data penelitian maka dapat disimpulkan mengenai penelitian ini adalah "Terdapat pengaruh latihan Ladder Drill terhadap peningkatan kelincahan pemain sepakbola UKM Universitas Siliwangi”

\section{DAFTAR PUSTAKA}

Bompa, T. Periodization: Theory and Methodology of Training. United States: Human Kinetics, 2015.
Brian Mackenzi. 101 Performance Evaluation Tests, London: Electric Word plc, 2015.

J. M. Sheppard a \& W. B. Young. Agility literature review: Classifications, training and testing. Journal of Sports Sciences Publication details, including instructions for authors and subscription, 2007. information:

http://www.tandfonline.com/loi/ rjsp20.

Matteo Zago, Massimo Giuriola and Chiarella Sforza1. 2016. Effects of a combined technique and agility program on youth soccer players' skills. International Journal of Sports Science \& Coaching Vol. 11(5) 710-720, 2016

Nikolaos Manouras, Zisis Papanikolaou, Konstantina Karatrantou, Polydoros Kouvarakis and Vassilis Gerodimos. 2016. The efficacy of vertical vs. horizontal: Plyometric training on speed, jumping performance and agility in soccer players. International Journal of Sports Science \& Coaching 0(0) 1-8 ! The Author(s) 2016 Reprints and permissions: sagepub.co.uk/journalsPermissi ons.nav DOI: $10.1177 / 1747954116667108$ spo.sagepub.com.

Reynolds. The Ultimate Agility Ladder Guide. Complements of Progressive Sporting Systems, Inc, 2011. 
Sugiono. Metodelogi Penelitian Kombinasi. Bandung: Alfabeta PT RinekaCipta, 2011.

Sukadiyanto. Melatih Fisik. Bandung: Lubuk Agung, 2011.

Warren Young \& Nathan Rogers. Effects of small-sided game and change-ofdirection training on reactive agility and changeofdirection speed. Journal of Sports Sciences, 2013.

Widiastuti. 2015. Tes dan Pengukuran Olahraga. Jakarta: Rinekacipta.

Lubis Johansyah. Panduan Praktis Penyusunan Program Latihan. Jakarta: Rajagrafindo, 2013.

Harsono. Kepelatihan Olahraga cetakan ke 2. Jakarta:Rosda, 2017. 